\title{
THE HABITUATION OF BEHAVIOR AS STUDENTS' CHARACTER REINFORCEMENT IN GLOBAL ERA
}

\author{
Santi Lisnawati \\ Universitas Ibn Khaldun \\ Jl. K. H. Sholeh Iskandar KM 2, Bogor, Jawa Barat, Indonesia 16162 \\ Email: santilisnawati@fai.uika-bogor.ac.id
}

\begin{abstract}
This study aims to investigate the implementation of students' habituation in schools and religious attitudes which are owned by them as an effort to strengthen positive behavior in globalization era. This research was conducted at Integrated Islamic Elementary School (SDIT) Insantama Bogor. The method used is descriptive qualitative method. The results showed that the school has a number of activities, with emphasis on habituation. Habituation at school refers to the value of the Islamic teachings. Since the entry gate to home school, students familiarize positive behavior. Students have a noble character or al-akhlãk al-karimah through habituation derived from value of Islam. The students at SDIT Insantama Bogor familiarize the positive behaviour, so that they have a noble character, such as having a character to Allah (loving Allah), behaving whole hearted, behaving honest, feeling self-confident, behaving emphatic, forgiving, saying well, behaving tolerant, and having the character towards environment by loving the nature and keeping the environment clean.
\end{abstract}

Keywords: Globalization, Habituation, Religious Attitude.

\begin{abstract}
ABSTRAK
Artikel ini bertujuan untuk memaparkan hasil penelitian tentang pelaksanaan pembiasaan peserta didik di sekolah dan sikap keagamaan yang dimiliki oleh mereka sebagai upaya untuk. memperkuat perilaku positif di era globalisasi. Penelitian dilakukan di Sekolah Dasar Islam Terpadu (SDIT) Insantama, Bogor. Metode penelitian yang digunakan adalah metode qualitatif deskriptif. Hasil penelitian menunjukkan bahwa di SDIT Insantama Bogor memiliki sejumlah aktivitas pembiasaan, dengan penekanan pada pembiasaan sejak masuk sampai pulang sekolah. Pembiasaan di sekolah mengacu pada nilai ajaran Islam. Peserta didik di SDIT Insantama Bogor membiasakan perilaku positif, sehingga peserta didik memiliki akblak yang mulia seperti berakblak kepada Allah (mencintai Allah), berlaku ikblas, bersikap jujur, percaya diri, empati, memaafkan, berkata baik, toleransi dan berakblak terhadap lingkungan dengan mencintai alam dan menjaga kebersihan lingkungan.
\end{abstract}

Kata Kunci: Globalisasi, Pembiasaan, Sikap Keagamaan. 


\section{INTRODUCTION}

High civilization of a nation is determined by individual's behavior or character inside it. The formation of behavior or character can be committed through education. The Law of Indonesian Republic, No. 20, Year 2003 states that the function of national education is to develop the ability and to form the disposition as well as the noble nation civilization in making the nation's life smart, aims to develop the potency so as to become the religious human and obedient to the Almighty God, noble, healthy, smart, capable, creative, independent, and become democratic and responsible citizen. The function of national education describes that the character formation is the main purpose of the education.

In Islamic view, education is a very important part in life. The Islamic teachings which were conveyed by the Prophet had the vision in changing the human's behavior, that was, to perfect the character (Sulaiman, Ismail, \& Yusof, 2013). Islam gives the direction in forming the individual's behavior through process of education derived from Islamic teachings. The Islamic teachings which are derived from al-Qur'an and the sunnah are the teachings which are in accordance with the human's disposition and precise for the cultured and civilized human along the age (Nata, 2009). In the Al-Qur'an presented implicitly the values of morals or characters (Subarkah, Ramawati, \& Dalli, 2016). Therefore Al-Qur'an and Al-Sunnah are foundation references in developmental morals or characters.

The process of education can be committed through three stripes, namely: formal education, non-formal education, and informal education. The formal education is a structured and gradual education stripe which consists of elementary, intermediate, and advanced education. The nonformal education is an educational stripe out of the formal education which can be implemented in a structured and gradual way. The informal education is a family and neighbourhood education stripe (The Law of Indonesian Republic, No. 20, Year 2003).

The three formal, non-formal, and informal education stripes are complementary with one another in educational missions. Family, society, and neighbourhood are the beginning foundation and hold the important roles in behavioural formation. Schools, as the formal education stripe, give the behavioural formation reinforcement in a more structured way because there is a curriculum as the reference. School, as one of the formal education places, is the place which is expected to give more contributions to the formation of behaviour or character (Khairi \& Othman, 2016).

Religion is essentially the good character (Al Ghazali, 2013). Let alone for the school which emphasizes the religion as rüb (spirit) in education, it forms students' character becoming responsible for all parties who are 
involved in education at school, like at SDIT (Integrated Islamic Elementary School/Sekolah Dasar Islam Terpadu). SDIT is the school which integrates the religion on every principle in its education as well as applies the system of full day school. This becomes a strategic place in managing the habit and discipline because the students spend more time at school.

One of the character formation methods at school is the habituation (Attaran, 2015; Ulwan, 2013). The character education is based not only on the understanding and knowledge but also through the process of habituation (Al Ghazali, 1997; Attaran, 2015). The activities of habituation train to do the positive behaviour at school especially religious behaviour. Students' experiences which are obtained through the habituation at school adhere and become a positive attitude in students. The positive habituation is committed to strengthen the religious attitude at school because the needs of religion are no longer avoidable. In globalization era, the religion becomes an important part for reinforcement of students' character in dealing with the global current.

The reinforcement of students' religious behavioural attitude needs to be implanted since early. Every teacher has the same role in giving the models and developing students' habit (Khairi \& Othman, 2016). However, implanting the religious attitude at school has a lot of obstacles. One of the obstacles is the existence of view which states that the one who should implant the religious attitude and the character for students is only the certain teachers, such as teacher of Religion and teacher of Citizenship Education. As a result, other teachers only focus more on the emphasis of students' cognitive ability (Khairi \& Othman, 2016).

This study aims to give the habitual description conducted at SDIT Insantama, Bogor, which is committed by all teachers and religious attitude which grows in students. The research was focused on aspect of habitual process by observing the activities and analyzing their relationship with the religious attitude.

The research method used is descriptive method. Descriptive method is one of the qualitative methods to describe process and values transformation in daily activities (Putra \& Lisnawati, 2012). The research aims to describe how to strengthen students' character at school. The research was conducted at SDIT Insantama, Bogor. Institutionally, the school at which the research was conducted is one of the oldest Integrated Islamic Elementary Schools in town and Bogor regency which has an A accreditation. The reason why chooses the research place because the elementary students are the effective time to implant the value, habit and behavior. This is because at this time the students are in behavioral formation. 
The research is focused on the process of activity taking place at school which is obtained through observation, interview, and documentary study. The observation was committed on the activities of students, teacher, and school environment to collect the behavior which strengthens students' character. The interview was committed on students, teacher, and school management. Students' behavioral sustainability was also confirmed with different condition and place (home) by interviewing the parents and handing out the questionnaires which were filled by students. The documentary study was committed to see the school program and its relationship in students' character reinforcement. The data were analyzed by using a qualitative analysis by doing the data collecting, data presenting, data reducing, and conclusion taking (Miles \& Huberman, 1992).

\section{DISCUSSION}

\section{The Role of Religion in Global Era}

The global discourse has run as time goes on entering the $21^{\text {st }}$ century. There are a number of characteristics which adhere to the global era. The global characteristics are marked by:

1. The mastery of communicative and informative technology. This time the power is viewed as the ability in mastering the access of communicative and informative technology. One who does not know this field will be left far away, like standing apart in the crowd. It is undeniable that in even educational world the technology and information have a very big role. If someone has deified the communicative and informative technology, what about the process of teaching, can it be replaced by technology? The wrong comprehension will bring a far distance in understanding the value of religious teachings with the power of technological current.

2. State without border, international cooperation will be very possible. The cooperation in various fields can be done internationally both for bilateral, regional, and international level. For instance, the agreement of ASEAN countries in economy joins the MEA (ASEAN Economic Society/ Masyarakat Ekonomi ASEAN). It contains the consequence for the members and the nation's society inside it. It is a challenge if taken positively, but it is a threat if taken negatively. The comprehension of ASEAN progress togetherness for everything becoming the shortcoming becomes a challenge to be fixed.

3. Cooperation versus international competition which is not easy to be avoided will be something which is regarded as the competition because of having the same needs over the need fulfillment and the life welfare. 
This can bring about an expansion in the field of trade, education and culture.

Globalization era actually offers an opportunity as the challenge to fix the shortcoming. The shared commitment feels that the weakness is the challenge and opportunity to be fixed. So, the globalization era is not a threat (Nata, 2009). Based on the characteristic of global era, the role of religion becomes more and more clear and important in strengthening individuals dealing with the global competition. The shift of deviate value and behavior becomes the beginning of soul unhealthiness. One is easy to be affected by current and anxiety. Therefore, the reinforcement of religion becomes very important in formation of behavior or character.

\section{Behavior or Character}

The word 'character' derives from Arabic, that is, kbuluqun, which means 'behavior, character, custom or kbalqun which means phenomenon and creation. Thereby, etymologically the character can be defined as behavior, disposition, custom, or the created behavioral system (Hasan, 2002). Character is the established spiritual condition (bai'ab) from someone's soul in behaving which can emerge spontaneously without speculation or consideration (Al Ghazali, 2013). The character is the unconscious pattern generated from habits in consistent daily life (Zuhdi, 2009).

In Islamic view, the character can be classified into two parts, namely: good character and bad character. Good character reflects the behavior which shows the values of religion, Islam and good deeds (Hasan, 2002). There are many forms of good character, among other things: 1) the character related to Allah as the creator, 2) the character related to interaction among humans, 3) the character related to environment (Shihab, 2007). This shows that there are some aspects which can be categorized in behaving which is known as the character, character to Allah, oneself, other people, and environment. All of them become unity in individual's life which cannot be separated.

On the contrary, bad character is the behavior which does not do the values of religion, Islam and good deeds. The bad character brings about the behavior which is disliked by other people, such as: bad-tempered, envious, arrogant, dishonest and rude.

Everybody lives in interaction and shows the behavior related to what he or she faces. Behavior or character derives from the value of Islamic teachings belonging to that good character which are familiarized to students, while the bad character is the behavior which emerges due to the weakness and stupidity. The character needs a social interaction in which we interact with other people (Cunha, Martins, \& André, 2016). 
The objective of Islamic education is to have the good religious attitude in everyone. The religious attitude is a behavioral tendency directing to noble character. Attitude is part of domain affection related to attention, attitude, and full comprehension (Linn \& Grundlund, 1995) The attitude will show up when it is faced to an object. The religious attitude can be identified based on the broadness of religious competence scope which needs possessing. The religious attitude has been proven to have contributions on individual's behavior. Hedwinusana, Sedanayasa, \& Mudjijono state that someone having the religious attitude will be able to avoid the deviate behaviour. This means that one who has the good religious attitude will be able to push down the deviate behaviour (Hedwinusana \& Sedanayasa, 2013).

\section{The Method of Habituation}

To extend to an ingrained behavior, the habituation is required to reinforce someone's character or behavior. The behavior implanted since early is much better because at this time children are in the right time to develop and form someone's behavior. Managing the good behavior needs doing since early. The roles of family and school are undeniable in the formation of character. The results of Saniapon's research showed that the habituation at PAUD (Early Age Child Education/Pendidikan Anak Usia Dini) could increase the discipline (Saniapon, 2013). The form of discipline built is the discipline in tiding up the stationery, keeping up with the activities of learning, and saying the prayers. The habituation at PAUD can also increase students' polite behavior (Hasnah, 2014).

The application of character values through religious and social attitude will work out well by involving the parents' roles at home and in the neighborhood (Zuwirna, 2015). One of the ways in improving and implanting the behaviour besides through teaching is through habituation (Ulwan, 2013). Teaching is a theoretical aspect in improvement and education, while habituation is a practical aspect in formation and preparation. Habituation is the thing which is proper to be done in the process of education. Something which is practiced will be much more developing and meaningful than a theory. As stated in the Hadith that "The best matter is something familiarized although it is a little" (H.R. Hakim).

\section{The Founding of Character at SDIT Insantama Bogor}

Students' character reinforcement at SDIT belongs to the school mission; that is, the integrative Islamic personality formation (Widjajakusuma, 2013). Besides being on religious dimension, the personality having the value and noble character becomes unity of each aspect in educational components. Synergy of each component in it becomes an unseparated thing. SDIT Insantama Bogor has been preparing the learning 
components, among other things: teachers, curriculum and means of infrastructure which are in accordance with various things becoming the basis of Islamic education at school. Islamic education becomes rũh in educational implementation at SDIT Insantama Bogor. Every teacher pays attention to students' character and behavior by giving the models and conducive environment.

The teachers giving the models to students and the conducive environment can create the strong character in students. It is also proven in the results of Wekke \& Sahlan's research that educating students' character at school is not only enough with the learning quality in the classroom or extra hours, but also necessarily with the conducive school culture, namely: habituation, model, and polite invitation (Suardi \& Sahlan, 2014).

Habituation becomes the important emphasis in reinforcing students' character at SDIT Insantama Bogor. The habituation of positive behavior at SDIT Insantama Bogor is committed from entering school to going home. The activities done every day in discipline become a habituation. These activities require supports of each component. There are two strategies in developing the discipline on students. The first one is through curriculum containing students' discipline which can be implemented by school. The second one is the discipline educational strategy which can be applied by parents, school, and educators (Ismail, Rohani, Abdul, Sufi, \& Yusoff, 2013).

The habituation is committed by all teachers and committed on all subjects. The headmaster emphasizes that every teacher at SDIT Insantama Bogor is teacher of religion, so that every teacher has the same obligation in paying attention to students' character. The school has a commitment in preparing the educators who have Islamic personality and noble character. The teachers teaching at SDIT Insantama Bogor have passed the selection, one of which emphasizes teachers' personality or character (Cahyono, 2014).

As investigated by Rahmawati, teachers' roles become important in developing the good character. Teachers act from the beginning of learning to the end of learning. In all the learning activities, teachers implant the values or character to the students. The result of habituation committed by the teachers showed the development of students' moral values (Rahmawati, 2014).

Table 1 describes the activities of habituation at SDIT Insantama Bogor when students arrive at school until they go back home. Data in the Table 1 were gained from the result of interview with the teachers at SDIT Insantama Bogor, reinforced by data from the result of observation which was conducted by researcher. 
Table 1. Description of Habituation.

\begin{tabular}{|c|c|c|}
\hline No. & Time & The Implanted Habituation \\
\hline 1. & $\begin{array}{l}\text { When arriving at school } \\
\text { gate. }\end{array}$ & $\begin{array}{l}\text { Teachers welcome and interact with the } \\
\text { arriving students. The students are } \\
\text { familiarized to say the greetings, smile and } \\
\text { greet the teachers and friends who have } \\
\text { arrived at school. }\end{array}$ \\
\hline 2. & When arriving in the class. & $\begin{array}{l}\text { Students are familiarized to neatly put the } \\
\text { shoes on the available shelf, keep the class } \\
\text { clean by not discarding the garbage carelessly } \\
\text { and keep themselves clean. Before the class } \\
\text { begins in the morning, teachers inspect the } \\
\text { classroom cleanliness and students' cleanliness } \\
\text { (fingernails, teeth, hair, and clothes). }\end{array}$ \\
\hline 3. & $\begin{array}{l}\text { In the beginning of } \\
\text { learning. }\end{array}$ & $\begin{array}{l}\text { Teacher asks the students to say the prayers } \\
\text { before studying. }\end{array}$ \\
\hline 4. & In the learning. & $\begin{array}{l}\text { Teachers condition the students to actively be } \\
\text { involved in the class. Teachers give an } \\
\text { appreciation to the active students, such as: } \\
\text { questioning, answering, doing the task, and } \\
\text { working together with their groups. The } \\
\text { appreciation is given in the form of value } \\
\text { written down on the score blackboard. }\end{array}$ \\
\hline 5. & When Duba time comes. & $\begin{array}{l}\text { Students are familiarized to perform Duba } \\
\text { prayer together in the classroom. After Duba } \\
\text { prayer, teacher gives short advice related to } \\
\text { character. }\end{array}$ \\
\hline 6. & When taking a break. & $\begin{array}{l}\text { Students are familiarized to eat and drink in } \\
\text { the sitting position, wash their hands before } \\
\text { eating, say grace before eating, and keep the } \\
\text { cleanliness. }\end{array}$ \\
\hline 7. & $\begin{array}{l}\text { When Zubur and Ashar } \\
\text { prayers come. }\end{array}$ & $\begin{array}{l}\text { When performing Zuhur and Ashar prayers in } \\
\text { the mosque, students are familiarized to put } \\
\text { sandals neatly, say the prayer for entering the } \\
\text { mosque, perform sunnah prayer before } \\
\text { obligatory prayer, recite the Quran, and } \\
\text { perform Zuhur and Ashar prayers together in } \\
\text { orderly and devout way. }\end{array}$ \\
\hline 8. & $\begin{array}{l}\text { When Monday-Thursday } \\
\text { come. }\end{array}$ & $\begin{array}{l}\text { On Mondays and Thursdays, students are } \\
\text { motivated to do sunnab fast. }\end{array}$ \\
\hline 9. & When leaving school. & $\begin{array}{l}\text { By the end of the class, students are } \\
\text { familiarized to say the prayers together, say } \\
\text { the greetings, and scatter in an orderly way. }\end{array}$ \\
\hline
\end{tabular}


The above habitual activities are carried out every day. The habituation is carried out to manure the courtesy towards teachers and friends, courtesy of studying, courtesy in the mosque, discipline, and to train prayers and sunnah fast.

The courtesy towards the teachers and friends among other things are saying the greetings if running into the others, behaving friendly, smiling, and behaving polite. The courtesy of studying is trained in the form of saying the prayers before studying, keeping up with the lessons well, behaving orderly, keeping the class clean, and keeping students' cleanliness. The courtesy in the mosque is trained in the form of saying the prayers for entering the mosque, performing sunnah prayer and reciting the Al-Qur'an, performing Zubur and Ashar prayers together in orderly and devout way, keeping the orderliness and the mosque cleanliness.

The implant of character committed at SDIT Insantama Bogor is equivalent to the educational concepts stated by Al-Ghazali, that is, the education implants the character to Allah, the character to parents, the character to eat, the character to drink, the character to environment, and the character to put on the clothes (Al Ghazali, 1997). It is also the same as stated by Shihab that the good characters are: 1) the character related to Allah as the creator, 2) the character related to interaction with human, and 3) the character related to environment (Shihab, 2007).

The activities of habituation at SDIT Insantama Bogor are committed in order to be familiar with doing the good deeds. The habituation also becomes one of the ways to form the character (Abdurrahman, 2016). The habituation in attempting to build the good behavior has to be done since early, as it will be easier to do. As stated in Malayan proverb that "melentur bulub, biarlah diwaktu rebungnya" (bamboo is easiest to be formed when its shoot is still young) (Daud, 2013). It is also the same as forming students' character. It will be easier to be done since early.

In the process of character formation at school, teachers can give the praise to students who behave good and obedient to school regulations, and give the prize to the students who show the moral value and the high character. For students breaking the rules, making the noise, not keeping the cleanliness, and showing another bad behavior are given a reprimand or a punishment (Khairi \& Othman, 2016).

At school, the habituation must be enforced by all stakeholders. Building the good behavior is not only a task for a teacher of Islamic Religion Education, but also a task for all teachers. Therefore, SDIT Insantama Bogor has emphasized that every teacher has a responsibility in religious education and paying good attention to students' character. Despite the teachers of certain subjects, they have an obligation to direct the religious habituation at 
school and give the models. Table 2 below describes teachers' involvement in formation of students' behavior and character.

Table 2. Teachers' Activities in Forming Students' Behavior Habituation.

\begin{tabular}{|c|c|c|}
\hline No. & Time & Teachers' Activities \\
\hline \multirow[t]{7}{*}{1.} & \multirow[t]{7}{*}{$\begin{array}{l}\text { Arriving at school } \\
\text { in the morning. }\end{array}$} & $\begin{array}{l}\text { Every day in turn a teacher welcomes students in } \\
\text { front of school gate. The teacher smiles and greets the } \\
\text { students. Students kiss the teacher's hand and } \\
\text { respond to interaction by smiling and greeting each } \\
\text { other. }\end{array}$ \\
\hline & & $\begin{array}{l}\text { The teachers discipline the students before entering } \\
\text { the classroom. The students are asked to march, and } \\
\text { then the teachers check out the cleanliness, such as: } \\
\text { fingernails, teeth, and students' clothes. }\end{array}$ \\
\hline & & The teachers ask the students to say the prayer. \\
\hline & & $\begin{array}{l}\text { The teachers and students interact in the process of } \\
\text { learning in accordance with the running lesson hours. } \\
\text { In the process of learning, the teachers give an } \\
\text { appreciation to the active students. }\end{array}$ \\
\hline & & $\begin{array}{l}\text { When } D u h a \text { time comes, the teachers invite students } \\
\text { to perform praying together with recitation which is } \\
\text { recited for the certain classes to check out the prayer } \\
\text { recitation. }\end{array}$ \\
\hline & & $\begin{array}{l}\text { The teachers inspect students' activity agenda at home } \\
\text { containing the prayer activities, reciting al-Qur'an, and } \\
\text { other activities. Students' daily activity agenda at } \\
\text { home are found out by their parents by giving the } \\
\text { parents' signature. }\end{array}$ \\
\hline & & $\begin{array}{l}\text { Teachers call the certain students who are considered } \\
\text { to need the teacher's guidance to dig their problem } \\
\text { and seek the way out together. }\end{array}$ \\
\hline \multirow[t]{2}{*}{2.} & \multirow[t]{2}{*}{$\begin{array}{l}\text { In the afternoon } \\
\text { when taking a } \\
\text { break and } Z \text { ubur } \\
\text { prayer. }\end{array}$} & $\begin{array}{l}\text { When Zubur prayer comes, the teacher invite students } \\
\text { to preform praying together. When waiting for the } \\
\text { obligatory prayer, students are familiarized to sit in an } \\
\text { orderly way and perform sunnah prayer or recite the } \\
\text { Quran. The teacher gives a short lecture after Zubur } \\
\text { prayer and gives an appreciation to the students who } \\
\text { keep the orderliness when performing praying. }\end{array}$ \\
\hline & & $\begin{array}{l}\text { When taking a break, the teachers interact with the } \\
\text { students in an informal activity, like listening to } \\
\text { students' stories and cracking a joke with one another. }\end{array}$ \\
\hline 3. & $\begin{array}{l}\text { In the afternoon } \\
\text { when performing. } \\
\text { Ashar prayer and }\end{array}$ & $\begin{array}{l}\text { The teachers invite the students from the } 3^{\text {rd }} \text { to } 6^{\text {th }} \\
\text { grades to perform Ashar prayer together. The students } \\
\text { in the } 1^{\text {st }} \text { and } 2^{\text {nd }} \text { grades have gone home at two }\end{array}$ \\
\hline
\end{tabular}




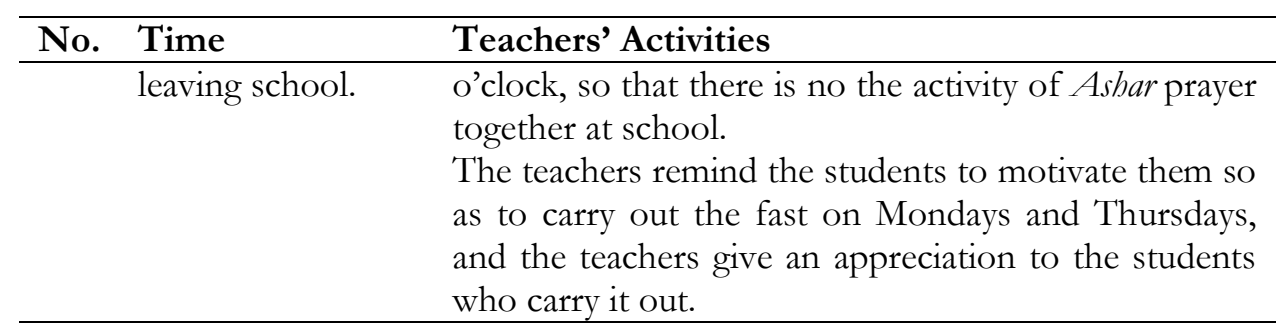

The activities in the Table 2 are regularly carried out by all teachers every day. Besides the routine activities, there are also the activities committed incidentally, such as: Ramadhan pesantren activities, commemoration of Islamic holiday, and social activities committed in reinforcing students' character. The incidental activities are carried out by all teachers.

From the results of observation at school, the habituation committed by students of SDIT Insantama Bogor gives contributions to students' positive behavior. The results of observation are reinforced by the same research results that the habituations of religious behavior, like saying the greetings, smiling, greeting, saying the prayers, reciting the al-Qur'an, and doing the sunnab fast have generated students' humble, tolerant, and polite character (Suardi \& Sahlan, 2014). The habituation at school also increases the discipline (Saniapon, 2013) and increases the polite behaviour (Hasnah, 2014).

Forming students' good habits is not only school's responsibility but also parents' obligation. In this case, the school has worked together with the parents to stand up for the good behaviour when the students are at home, like performing the obligatory prayers and sunnab prayers, reciting the alQur'an, covering all parts of body except face and hands, and restricting watching TV at home. The results of interview with parents showed that the parents did not go through difficulties to direct their children doing the good habits implanted at school, especially to students from the $4^{\text {th }}$ grade and up.

"When the children enter the $4^{\text {th }}$ grade, there are a lot of changes in them. If they are in the low grades (1-3), they still need persuasions very much, so as to be able to perform praying or reciting the al-Qur'an; nevertheless, after the $4^{\text {th }}$ grade the children themselves do the activities without being persuaded or asked" (FOSIS/ Forum Orang Tua Siswa SDIT Insantama Bogor, 2014).

The change of students' behaviour conveyed by the parents above is the result of the repetitive habit at school and has become the awareness. This habit has become the part in students. As stated by Al Ghazali and Zuhdi that the behaviour emerges spontaneously without speculation and consideration which constitute the pattern which is not realized and 
generated from the habits in the consistent daily life (Al Ghazali, 2013; Zuhdi, 2009). The next stage of the habit is the awareness of habituation. The awareness of habituation burgeons as the development of thinking goes on.

To gain the data of students' character tendency, the questionnaires were given to the students. The questionnaire contains the statement about character to Allah (loving Allah and behaving wholehearted), character to themselves (behaving honest, self-confident, emphatic, forgiving, saying well, tolerant), and character to environment (loving the nature and keeping the environment clean). The data gained from the questionnaire can be seen in the Table 3.

Table 3. Data of Students' Character Tendency.

\begin{tabular}{|c|c|c|c|}
\hline No. & Dimension & Sub Dimension & Average \\
\hline \multirow{2}{*}{1.} & \multirow{2}{*}{ Character to Allah. } & Loving Allah & $92 \%$ \\
\hline & & Whole-hearted & $97 \%$ \\
\hline \multirow{3}{*}{2.} & \multirow{3}{*}{$\begin{array}{l}\text { Character to } \\
\text { themselves. }\end{array}$} & Honest & $92 \%$ \\
\hline & & Disciplinary & $89 \%$ \\
\hline & & Self-confident & $78 \%$ \\
\hline \multirow{4}{*}{3.} & \multirow{4}{*}{ Character to the others. } & Emphatic & $83 \%$ \\
\hline & & Forgiving & $84 \%$ \\
\hline & & Saying well & $88 \%$ \\
\hline & & Tolerant & $83 \%$ \\
\hline \multirow[b]{2}{*}{4.} & \multirow{2}{*}{$\begin{array}{l}\text { Character to } \\
\text { environment. }\end{array}$} & Loving the nature & $86 \%$ \\
\hline & & $\begin{array}{l}\text { Keeping the } \\
\text { environment clean }\end{array}$ & $94 \%$ \\
\hline & Average & & $88 \%$ \\
\hline
\end{tabular}

Character to Allah has a high percentage. It means that in akidah and taubid the students know that only Allah becomes the basis in doing the worship. Character to themselves, other people and environment also has the high percentage. The students are able to show the best behavior for themselves, other people, and environment. The average of percentage of the students' character tendency acquires $88 \%$.

Character to Allah is the contributions of the habituation pattern committed at school, among other things are: the habit of praying together, praying Duba, fasting sunnah, and the advice conveyed by the teachers. In addition, while the process of learning is taking place, the process of love internalization to Allah is committed through the subjects as committed by 
Subarkah et al., (2016). Teachers' comprehensions and experiences in applying the pattern of habituation at school are very important (Fakhruddin, Alwi, Hamzah, Bahasa, \& Sains, 2013). Teachers, in this case, act in giving the example of good worship practice. The pattern of habituation formed at school is tired to be defended until at home as students' second environment through working together between the stakeholders and the parents.

Character to themselves which is built shows honest, disciplinary, and good self-confident attitude. The honest attitude, in some cases, is a problem which frequently emerges in educational world. Alireza (2012), in his results of research, found the process of dishonesty during the process of learning in the class, like cheating. Therefore, the pattern of habituation in implanting the honest attitude is very important. The activity of honest habituation is committed in the process of learning. For instance, in the test the students are emphasized to do it by themselves without asking or giving the answers to the other students. The teachers also emphasize the students to have the discipline in keeping up with the activity of learning, come to the school on time, put the items in their place, put the shoes on the available shelf, put away the items after use, keep the class clean by not discarding the garbage carelessly, and keep themselves clean. In the morning the teachers inspect the class cleanliness and students' cleanliness (fingernails, teeth, hair and clothes). Students' self-confidence is built by way of the praises given by the teachers over the behaviour and achievement acquired by the students. The students showing the high interest when the class is taking place, such as questioning, answering, doing the task, being able to work together in groups, are given the value which is written on the score blackboard.

The results of questionnaire show that the character related to other people and environment also shows the good result. Character to other people which is emphasized is emphatic, forgiving, saying well, and tolerant. The character to other people is the social interaction among students, students and teachers, and students and parents. The students are familiarized to help each other if there is a friend who needs some helps, and see the sick friend as the emphatic form. The forgiving attitude and the tolerance seem from the minimum of quarrel among students. Meanwhile, the habituations by saying the greetings, smiling, and greeting if running into teachers, parents, or other friends direct the students to say well.

The students' attitude in dealing with a situation or an object is a reflection of character and becomes a concept in self. A self-concept is the cohesiveness between knowledge and deed, guided by a clean heart as the basis of the belief. The self-concept in Al Ghazali's concept is named tarkiyat an-nafs, encompassing three elements, namely: belief, knowledge, and deed (Jaafar, Halim, Asiah, \& Muhamad, 2012). 
The habituation of positive behaviour enforced at SDIT Insantama Bogor has a harmony with the religious attitude derived from the values of Islamic teachings. The behaviour which is continuously committed will be a habituation and adhere to oneself. It needs no a long time by repeating 60 times, something which is continually repeated will be a habituation (Keller \& Papasan, 2013). What is said in the meaning of character according to Al Ghazali can be explained that a repetitious behavior will be an ingrained behavior when the same condition emerges spontaneously. Familiarizing a good behavior is equally as difficult as familiarizing a bad behavior. If so, it does not need to waste the time by familiarizing something bad. The good character is a token of someone's ability in managing the emotion. The emotionally smart people are those who have the noble character (Abdullah Kamal \& Ghani, 2014).

The change of individual's behavior due to the continuous practice will be an ingrained behavior (Atkinson, Atkonso, Smith, \& Bem, 2000). The learning of habituation needs to be accompanied by a comprehension in order that there are no forms of static, mechanical, and meaningless habituation (Ramayulis, 2010). Thereby, the habituation will be meaningful when it is accompanied by the comprehension and in the long run will give the positive effects on religious attitude.

\section{CONCLUSION}

There are a number of habituations applied to the students of SDIT Insantama Bogor from entering to leaving school. The habituations are committed by all teachers. The habituations committed have contributions to the religious attitude. The religious attitude is a tendency of behavior directing to behavior or noble character. The character which is successfully built at SDIT Insantama Bogor is the character to Allah by loving Allah and behaving whole hearted, the character to themselves related to honesty, selfconfidence, empathy, forgiving, saying well, and tolerance, the character to environment by loving the nature and keeping the environment clean.

\section{ACKNOWLEDGEMENTS}

The author wishes to thank the Faculty of Islamic Religion giving the space and supports to conduct the research. Furthermore, the author thanks the Headmaster of Insantama Bogor who has given the field permission to conduct the research.

\section{BIBLIOGRAPHY}

Abdullah Kamal, S. S. L., \& Ghani, F. A. (2014). Emotional intelligence and akhlak among muslim adolescents in one of the islamic schools in johor, 
south malaysia. 4th World Conference on Psychology, Counseling and Guidance, 114(1997), 687-692. http://doi.org/10.1016/j.sbspro.2013.12.768.

Abdurrahman, N. H. (2016). Character education in islamic boarding schoolbased sma amanah. Jurnal Pendidikan Islam, 2(2), 287-305. Retrieved from https://doi.org/10.15575/jpi.v2i2.791

Al Ghazali. (1997). Mutiara ibya ulumuddin. Bandung: Mizan.

Al Ghazali (2013). Metode menaklukan jiwa. Terjemahan Rahmani Astuti. Jakarta: Mizan.

Atkinson, R. L., Atkonso, R. C., Smith, E. E., \& Bem, D. J. (2000). Pengantar psikologi. Batam: Aksara.

Attaran, M. (2015). Moral education, habituation, and divine assistance in view of ghazali. Journal of Research on Christian Education, 24(1), 43-51. Retrieved from http://doi.org/10.1080/10656219.2015.1008083.

Cahyono, E. A. (2014, November 12). The habbituation at sdit insantama bogor. (S. Lisnawati, Interviewer).

Cunha, M., Martins, R., \& André, S. (2016). Ethical-moral courses of action and active citizenship in health students, 217, 329-336. Retrieved from http://doi.org/10.1016/j.sbspro.2016.02.096.

Daud, W. M. N. W. (2013). Islamsasi ilmu-ilmu kontempores dan peran universitas islam dalam konteks dewesternisasi dan demokrasi. Bogor: Ibn Khaldun-UTM.

Fakhruddin, F. M., Alwi, N. H., Hamzah, A., Bahasa, J. P., \& Sains, J. P. (2013). Pemahaman dan pengalaman guru pendidikan islam menerapkan elemen amalan dalam pengajaran, 1(1), 1-16.

FOSIS/ Forum Orang Tua Siswa SDIT Insantama Bogor. (2014, December 2014). Students' habbitation at home. (S. Lisnawati, Interviewer).

Ghazali. (1997). Mutiara ibya 'ulumuddin. Bandung: Mizan.

Hasan, M. (2002). Membentuk pribadi muslim. Yogyakarta: Pustaka Nabawi.

Hasnah. (2014). Upaya menembangkan perilaku sopan melalui pembiasaan pada anak kelompok b1 di tk al khairaat tondo. Jurnal Bungamputi, Pendidikan Anak Usia Dini, 2(9), 794-800.

Hedwinusana, I Wy Gede, d Sidayana \& Mudjiono (2014) Kontribusi sikap keagamaan terhadap perilaku menyimpang peserta didik smp negeri 2 singaraja tahun pelajaran 2012/2013. E-jurnal.com.

Ismail, M., Rohani, P., Abdul, M., Sufi, M., \& Yusoff, M. (2013). Educational strategies to develop discipline among students from the islamic perspectives. Procedia - Social and Behavioral Sciences, 107, 80-87. http://doi.org/10.1016/j.sbspro.2013.12.402.

Jaafar, N., Halim, A., Asiah, N., \& Muhamad, F. (2012). The importance of self-efficacy : a need for islamic teachers as murabbi. Procedia - Social and Behavioral Sciences, 69(Iceepsy), 359-366. http://doi.org/10.1016/j.sbspro.2012.11.421. 
Keller, G., \& Papasan, J. (2013). The one thing, kekuatan fokus untuk mendorong produktivitas. Jakarta: Gramedia.

Khairi, M., \& Othman, H. (2016). Pembentukan akhlak pelajar menerusi aplikasi teknik-teknik penerapan nilai dalam pengajaran. The Online Journal Islamic Education, 4(1), 58-70.

Linn, R. L., \& Grundlund, N. E. (1995). Mesurement and assessement in teaching. New Jersey: Perntice Hall.

Miles, M. B., \& Huberman. (1992). Analisis data kualitatif. Jakarta: UI Press.

Nata, A. (2009). Urgensi pendidikan agama di era global. In Mereka Bicara Pendidikan Islam Sebuah Bunga Rampai (p. 52). Jakarta: RajaGrafindo.

Putra, N., \& Lisnawati, S. (2012). Penelitian kualitatif pendidikan agama islam. Bandung: PT. Remaja Rosdakarya.

Rahmawati. (2014). Peranan guru dalam mengembangkan kemampuan nilai moral anak kelompok b tk aisyiyah v palu. Bungamputi, Jurnal Pendidikan Anak Usia Dini, 2(9), 762-771.

Ramayulis. (2010). Metodologi pendidikan agama islam. Jakarta: Kalam Mulia.

Saniapon, A. (2013). Meningkatkan kedisiplinan anak melalui pembiasaan di kelompok b paud negeri pembina palu, Jurnal Bungamputi, Pendidikan Anak Usia Dini, 2(8)665-678.

Shihab, M. Q. (2007). Wawasan al quran. Bandung: Mizan.

Suardi, I., \& Sahlan, A. (2014). Strategy in creating school environment: lessons from high schools in indonesia. Procedia - Social and Behavioral Sciences, 143, 112-116. http://doi.org/10.1016/j.sbspro.2014.07.370.

Subarkah, C. Z., Ramawati, R., \& Dalli, A. (2016). Internalizing islamic values in electrochemistry learning. Jurnal Pendidikan Islam, 2(2), 270-286.

Sulaiman, H., Ismail, Z., \& Yusof, R. (2013). Kecerdasan emosi menurut alquran dan al-sunnah : aplikasinya dalam membentuk akhlak remaja, The Online Journal of Islamic Education, 1(2), 51-57. Retrieved from http:/ / repository.um.edu.my/id/eprint/907

Ulwan, A. N. (2013). Tarbiyatul aulad. Jakarta: Khatulistiwa Press.

Widjajakusuma, M. K. (2013). Pernyataan identitas dalam 12 tahun insantama, 5.

Zuhdi, D. (2009). Humanisasi pendidikan. Jakarta: Bumi Aksara.

Zuwirna. (2015). Penerapan nilai-nilai karakter melalui sikap keagmaan dan sikap sosial pada siswa sd studi kasus di sd negeri 03 alai kota padang. Jurnal Ilmiah Ilmu Pendidikan, XV(1), 40-46. Retrieved from http:/ / ejournal.unp.ac.id/index.php/pedagogi 